\title{
TENANT PARTICIPATION IN SOCIAL HOUSING STOCK MANAGEMENT
}

\author{
Katarzyna Suszyńska, PhD \\ Department of Investment and Real Estate \\ Poznań University of Economics \\ e-mail:katarzyna.suszynska@ue.poznan.pl
}

\begin{abstract}
The aim of this paper is to present the concept, classification and significance of the involvement of tenants in the processes of managing council flats. Tenant participation is becoming an increasingly popular subject of research owing to numerous benefits in the field of social housing stock management, such as better adjustment of property managers' services to tenants' needs and preferences, or an increase in the efficiency and economics of management. However, the mobilization of tenants will be successful only if they can participate in the decision-making process in a relatively high degree. Our discussion focuses on social housing stock in Poland.
\end{abstract}

Key words: tenant participation, social participation, social housing.

JEL Classification: A13.

Citation: Suszyńska K., 2015, Tenant Participation in Social Housing Stock Management, Real Estate Management and Valuation, Vol. 23, No. 3, pp. 47-53.

DOI: $10.1515 /$ remav-2015-0024

\section{Introduction}

The aim of this paper is to present the concept, classification and significance of the involvement of tenants in the processes of managing social housing. The concept of social housing is not only subject to ongoing changes in time, but also varies across countries, depending on the type of housing policy pursued by the state. Hence, the body of world literature does not provide any homogeneous definition of social housing. An overview of the definitions and scope of the term "social housing" shows that such flats have the following attributes, which are common for most European countries:

- subsidizing the construction of flats or maintenance of housing stock with funds from the state budget or commune budgets,

- the construction and management of housing stock are the responsibility of local governments or professional profit-oriented housing organizations,

- establishing a rental fee below the market level and/or using other forms of protecting tenants,

- renting flats usually on the basis of the household's family situation and level of income.

In case of the first of the above-mentioned features, we may observe a tendency - common for most systems - to depart from interfering with the sphere of social housing, i.e.:

1) governments abandon large-scale housing programs and focus on precise and selective assistance targeted at those citizens whose accommodation needs are met to the lowest degree,

2) in most European countries, governments are no longer the most important "players" in the housing sector. A large part of dwelling stock has already been privatized. A lot fewer new social flats financed by the public sector are being built,

3) social housing stock management is becoming the responsibility of the private sector. Even though these functions have continued to be fulfilled by public institutions in some countries, local governments demand that market rules be used. It is becoming more and more common 
(e.g. in the Netherlands or Sweden) for local governments to establish the required profitability of public housing organizations on the basis of data from the private sector.

The management of council flats involves, among other things, an obligation to fulfil statutory social tasks with the simultaneous pursuit of the necessary financial targets. Moreover, the position of tenants in their relation to the landlord-manager has recently become much stronger. Until recently, managers of council flats marginalized (or even negated) tenants' attempts to get involved in housing matters. Under new circumstances, a tenant has turned into a customer, a council flat has become a market commodity, while all services provided to tenants are now free market services (SUSZYŃSKA, BARCZAK, p. 7). The new, co-management-based approach has brought about a number of improvements in the field of management, such as (DAVIES 1992, p.5):

- lower maintenance and renovation costs,

- an increase in the functionality of a housing area,

- property managers' increased satisfaction with their work,

- increased satisfaction of residents,

- more care given to the cleanliness and beauty of housing estates,

- a reduction in the number of uninhabited flats and a shorter time taken to rent them again.

\section{The concept of social participation}

What is an important notion from the point of view of social housing management is social economy. It is connected with the creation of the so-called participatory democracy of tenants, proposing a new vision of social order and of the integration of local networks. The authors of recent works concerning social housing pay a lot of attention to the concept of social participation. This idea derives from the traditional theory of democracy, which assumes that every citizen has a right to express their opinions and to have a say when decisions of fundamental importance to the nation are made (FENSICL 1993, p. 7). According to J. Kwiatkowski, this term refers to becoming involved in the decision-making process at the local level, as well as to contributing to solving problems which have accumulated in the nearest neighborhood. In other words, citizen participation means the activity of parties involved in the preparation of plans and procedures of the implementation of the set policies in order to create a new, better reality (KWIATKOWSKI 2003, p. 8).

The most often cited classification of public participation is the so-called ladder of citizen participation proposed by S. Arnstein. Having analyzed the involvement of citizens in different fields of public life (mainly in the sphere of politics), the author posed a thesis that participation is a precondition of citizen power (citizens' decision-making powers).

The typology proposed by Arnstein divides participation into eight levels of citizen participation. When citizens reach the highest level, it means that they have full decision-making powers. The lowest rungs of the ladder, i.e. manipulation or therapy, constitute the level of non-participation. At this stage, people in power only inform citizens on basic issues (not granting them any real influence on decision-making), which results in a significant reduction of citizen nihilism. At the higher level, people receive deeper information and have the possibility of consulting projects. Citizens are placated through the so-called policy of tokenism, which in turn makes it possible for them to listen to other people's opinions and express their own views. However, they still do not have full decisionmaking powers. Partnership, delegated power and citizen control are the highest rungs of power, which constitute the last level of participation - the so-called citizen power. As they reach this ultimate level, citizens obtain a real and tangible influence on strategic decisions.

Tenant participation is one of the components of social participation. B. Bengtsson defines it as "collective action within the framework of a local housing estate." In his publication, the author explains the definition and expounds on all determinants of the concept. He emphasizes that tenant participation often goes beyond the relation between a tenant and the owner/manager of a property. This often translates into initiatives aimed at the improvement of the functioning of housing estates and at increasing their attractiveness, e.g. through establishing playgrounds or renovating street furniture in the estate. Tenants' initiatives often address geographically much broader issues, such as environmental protection or opposing a housing policy of local officials (BENGTSSON 1995, pp. 4-12). 


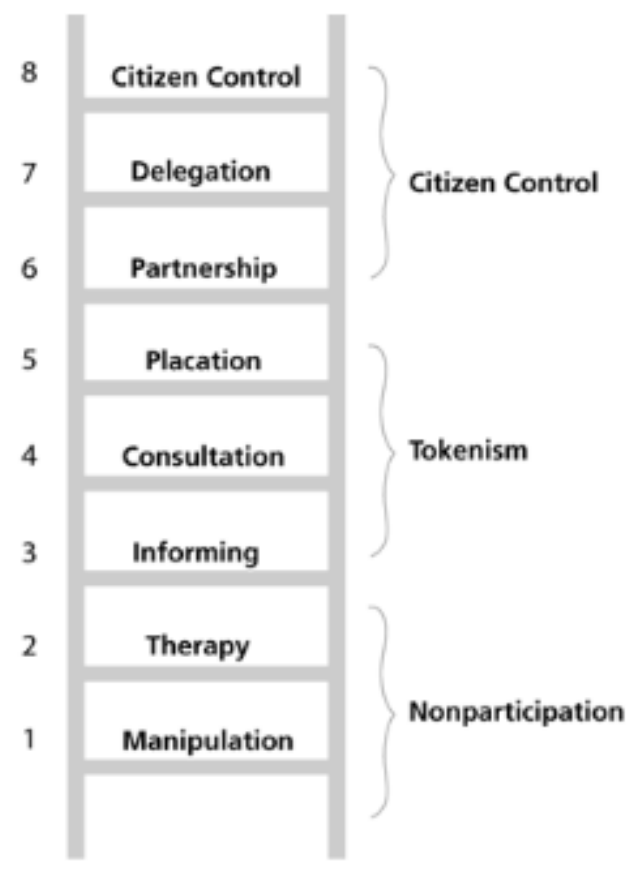

Fig. 1. Levels of participation according to S. Arnstein. Source: compiled by the author on the basis of (ARNSTEIN 1969, p. 27).

\section{The role of tenants in social housing management systems}

In the literature on housing issues, more and more attention is being paid to tenant movements (e.g. (SOMERVILLE 1995; YIP 2001; BENGTSSON and BERGER 2005; SCB REPORT 2005; BOVERKET 2010; BILLETER et al., 2011). The principal aim of the mobilization of tenants is to provide them with the possibility of having a real influence on the choice and methods of implementing best management practices within a building or a housing estate, which results in the better adjustment of services to customers' needs and preferences, and in the improved efficiency of management. The other key issue is the willingness to enhance participatory democracy through the activation of tenants (TAYLOR 2003, p. 191).

L.Cairncross, D. Clapham and R. Goodlad (Cairncross et al. 1997, p. 20) observed three types of tenant involvement in the management of flats. In the first, traditional model, tenants do not get engaged in management, leaving this task to professional managers or to local governments at the level of conceptual solutions. Tenants become here the passive recipients of a management system. The second model, the so-called consumer model, emerged in the 1990s with the development of the consumer paradigm in the sphere of public services. It assumes that a lessee should be treated as a customer of commercial enterprises and should receive services of required quality. Tenants are supposed to be the best source of information about the quality of service. The third model, the socalled citizen model, is based on tenants' massive and intensive participation in management activity through dialogue, consultation, or jointly-made decisions. It assumes that the mobilization of residents at the level of a building/housing estate will translate into bigger involvement of citizens and pro-democratic social behaviors (CHAPMAN and KIRK 2001, p. 38).

Redmond and Norris distinguished four levels of tenant participation:

Table 1

Levels, objectives and methods of implementing tenant participation programs

\begin{tabular}{lll}
\hline $\begin{array}{l}\text { Levels of tenant } \\
\text { participation }\end{array}$ & Objectives & $\begin{array}{l}\text { Methods and } \\
\text { mechanisms of } \\
\text { implementation }\end{array}$ \\
\hline Information & $\begin{array}{l}\text { Tenants receive } \\
\text { information on } \\
\text { housing issues }\end{array}$ & $\begin{array}{l}\text { Bulletins, meetings, } \\
\text { leaflets, tenant guides }\end{array}$ \\
\hline
\end{tabular}




\begin{tabular}{|c|c|c|}
\hline $\begin{array}{l}\text { Levels of tenant } \\
\text { participation }\end{array}$ & Objectives & $\begin{array}{l}\text { Methods and } \\
\text { mechanisms of } \\
\text { implementation }\end{array}$ \\
\hline $\begin{array}{l}\text { Consultation and } \\
\text { dialogue }\end{array}$ & $\begin{array}{l}\text { Tenants' opinions } \\
\text { are gathered and } \\
\text { taken into } \\
\text { consideration when } \\
\text { making decisions } \\
\text { and providing } \\
\text { services }\end{array}$ & $\begin{array}{l}\text { Open meetings; surveys } \\
\text { conducted among } \\
\text { residents, "discussion } \\
\text { panels" attended by the } \\
\text { inhabitants of an estate }\end{array}$ \\
\hline $\begin{array}{l}\text { Joint decision- } \\
\text { making or } \\
\text { decentralization }\end{array}$ & $\begin{array}{l}\text { Tenants vote on the } \\
\text { issues related to } \\
\text { service provision, } \\
\text { so local } \\
\text { governments have } \\
\text { to take their } \\
\text { opinions into } \\
\text { account }\end{array}$ & $\begin{array}{l}\text { "Discussion panels" } \\
\text { attended by the } \\
\text { inhabitants of an estate, } \\
\text { agreements between } \\
\text { landlords and tenants } \\
\text { affiliated with } \\
\text { associations; strategies } \\
\text { and plans of action }\end{array}$ \\
\hline $\begin{array}{l}\text { Management by } \\
\text { tenants }\end{array}$ & $\begin{array}{l}\text { Tenants have full } \\
\text { control and make } \\
\text { autonomous } \\
\text { decisions } \\
\text { concerning housing } \\
\text { issues }\end{array}$ & $\begin{array}{l}\text { Management is carried } \\
\text { out by tenants and tenant } \\
\text { associations }\end{array}$ \\
\hline
\end{tabular}

Source: (REDMOND, NORRIS 2007, p. 6).

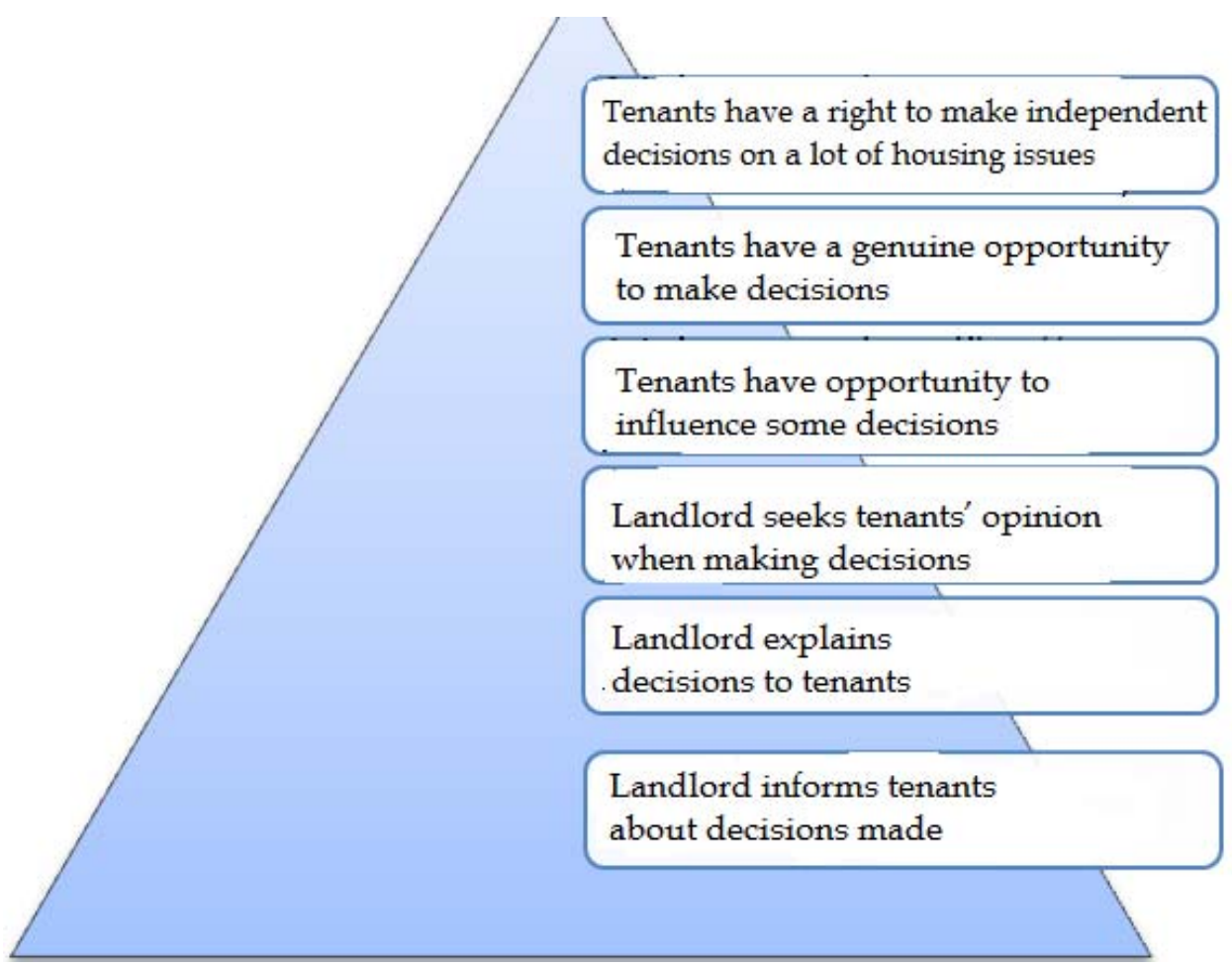

Fig. 2. Levels of tenant participation according to H. Ward. Source: compiled by the author on the basis of (WARD 1992, p. 153). 
H. Ward used S. Arnstein's ladder of participation to develop his own model classifying levels of tenant participation. Tenants' activity is expressed by their engagement in deciding on the services they receive (WARD 1992, p. 153).

The author makes a distinction between two types of tenant participation. The first of them (levels 1-3) involves so-called consultation. At this stage, the landlord (property manager) is the only decision-maker, who does not have structural solutions and tools to offer to tenants so that they could take active part in management. The upper part of the ladder signifies a genuine influence of tenants upon decisions regarding the management of properties they inhabit.

\section{The level of tenant participation in social housing stock in Poland as shown by surveys}

A tendency observed in Europe to enhance the emphasis on democratization and on the philosophy of public responsibility in social housing management was the reason for which we decided to examine the level of social and tenant mobilization at a selected local market. The survey was conducted between April and August 2013. The population, in broad terms, comprised the inhabitants of social rental flats, and the survey was conducted on a group of tenants of the Social Housing Association (Pol. TBS - Towarzystwo Budownictwa Społecznego) and of council flats in Poznań. The sample size was $n=199$. One hundred surveys were collected among the inhabitants of the municipal stock, while the residents of TBS flats located in Poznań returned 99 surveys.

For the sake of this paper, a research tool - a survey questionnaire - was developed. The respondents were asked to express their opinions on the quality of the management of flats, as well as buildings and areas surrounding them. Questions concerning the place of residence and housing environment management were asked in order to identify differences in the perception of management quality in the municipal stock and in TBS. Moreover, we intended to check whether this assessment was reflected in the level of tenants' involvement in housing issues.

On the basis of the definitions of social and tenant participation adopted for the sake of this paper, we designed a questionnaire verifying the respondents' engagement in social life and issues connected with council flats.

In order to identify the level of social participation, the respondents were asked to describe their activity in a number of social issues (e.g. social functions they hold, participation in elections, meetings, social campaigns, activity on Internet forums). The results are presented below (Fig. 3).

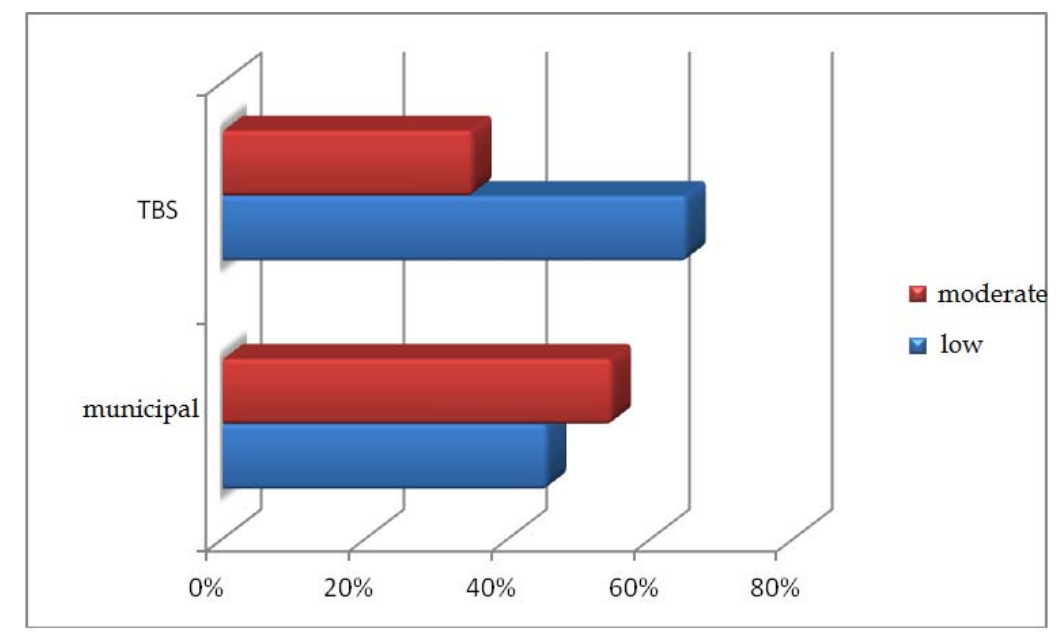

Fig. 3. Social activity of the inhabitants of social flats in Poznań as shown by surveys. Source: compiled by the author.

On the basis of numerous criteria, broadly defined activity of people under survey was identified as moderate or low.

The next step was to identify the level of the tenant participation of the respondents. To this end, we asked a number of questions about, among other things, the initiation of and support for campaigns concerning issues important for the whole housing estate, the degree of tenants' knowledge regarding matters related to their flat or building, as well as factors which the respondents considered to be the determinants of their greater involvement in housing issues. 


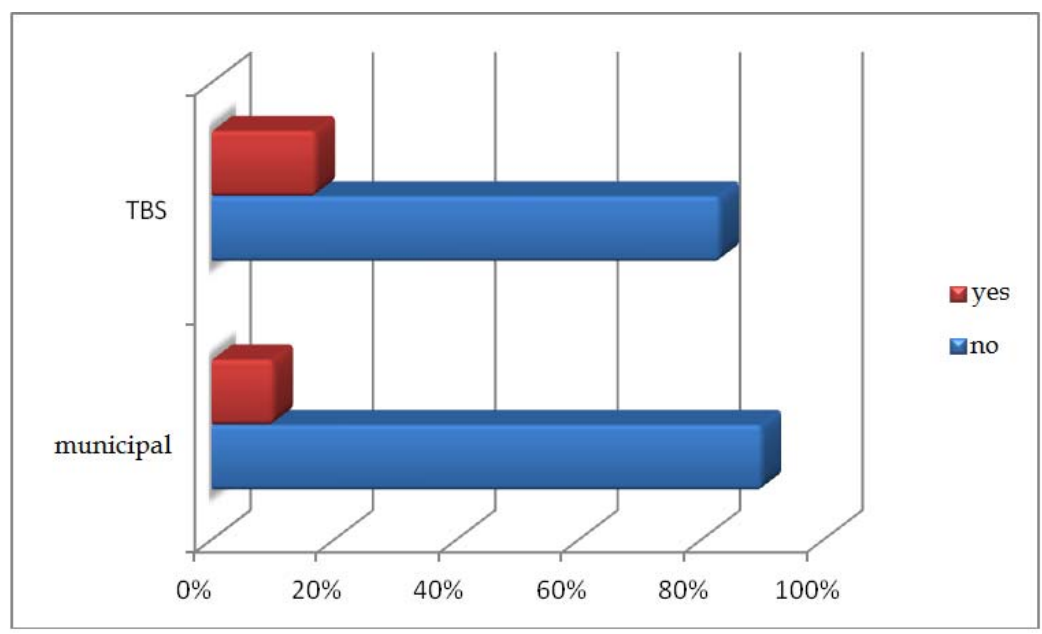

Fig. 41. Social participation of the inhabitants of social flats in Poznan as shown by surveys. Source: compiled by the author.

The obtained answers, first of all, show that the respondents coming from both types of stock had a sense of having no real influence on their housing environment. They did not initiate any changes within their buildings or housing estates. They seldom sought information on the management of properties they inhabited. Referring to the models proposed by L.Cairncross, D. Clapham and R. Goodlad, it must be concluded that it is the first of the management models presented by the above authors that is predominant in the local social housing stock - namely, tenants are only passive recipients of the management system (CAIRNCROSS et al. 1997, p. 20).

It would be difficult, however, to exclusively blame tenants for their lack of involvement in housing matters; this is largely caused by the attitude of owners or the administration (the lack of meetings with tenants, not consulting housing issues with them, and the lack of attempts to integrate and mobilize residents), as well as of the legislator (no legal regulations concerning tenant activity, the absence of mechanisms for the establishment and operation of tenant associations), etc. Thus, the observed model can be fit neither into the model of H. Ward's "ladder" nor into Redmond and Norris's four-level model, as even the first level of participation has not been achieved in the stock under survey.

\section{Conclusion}

In the light of the surveys conducted and of the analysis of literature concerning solutions in the field of social housing, it should be noted that the level of tenant participation of the inhabitants of council flats in Poland is low and steps must be taken to enhance the tenants' activity in the sphere of management.

If the role of tenants is to be increased, a long-term and multi-layer implementation plan is needed. It should be based on the establishment of:

- the foundations for the education of civil society, including:

- the foundations for the education on the joint management of social housing stock,

- the launch of a system promoting successful examples - models of cooperation in social housing stock management - in the form of, for example, special programs in mass-media, etc.,

- the development of research into models of joint management of social housing stock, and promoting good solutions in this area, developed in economies with advanced social housing systems.

Most Western European countries introduced provisions concerning the active role of tenants to their fundamental statutes regulating housing management. There is no doubt that the state should provide legal basis for the participation of social housing tenants in the management of this stock.

Moreover, formal and hierarchical structures of the organization of tenants at the local and central level should be established. They will provide citizens with the opportunity to influence social housing management processes. There are only a few such organizations in Poland and, what is more, these are small and scattered. Their main concern is the execution of tenants' rights, legal 
assistance in issues related to lease agreements, and taking legal action. The analysis of their statutes and objectives shows that they fail to mobilize tenants to participate in the management of flats. It should be added that if the issue of the tenants' influence on housing matters was regulated by law, tenant associations - which are currently organizations of people seeking compensation - would become organizations of active tenants, who are willing to introduce changes.

\section{References}

ARNSTEIN S., Ladder of Citizen Participation, in: Journal of the American Institute of Planners, No. 35, 1969.

BENGTSSON B., Housing - Market Commodity of the Welfare State, materials of the Institute of Housing Research, Gävle 1995.

BENGTSSON B., BERGER S., Gräsrot, språkrör och träffpunkt - lokala organisering och demokrati $i$ boendet, Forskningsrapport 2005:1, Gävle 2005.

BILETTER, A., BREWER, S., GALVIN, J., National Housing for Older People Awards 2011, Elderly Accommodation Counsel, London, 2011.

Cairncross L., Clapham D., Goodlad R., Housing Management, Consumers and Citizens, Routledge, New York 1997.

CHAPMAN M., KIRK K., Lessons for Community Capacity Building: A Summary of Research Evidence, Scottish Homes, Edinburgh 2001.

DAviES CH., Housing for Life. A Guide to Housing Management Practices, E. \& F. N. Spon Publisher, London 1992.

DODSON J., The "Roll” of the State: Government, Neoliberalism and Housing Assistance in Four

Advanced Economies, in: Housing, Theory and Society, Vol. 23, No. 4, Routledge 2006.

FENISCL T., Settlement Planning and Participation, in: Progress in Planning, Vol. 139, No. 2, 1993.

FRĄCZAK P., Wymiar polityczny, własność społeczna i hybrydowość jako elementy myślenia o zarządzaniu przedsiębiorstwem społecznym, in: Ekonomia Społeczna, No. 2/2008(3), Kraków 2008.

HARlOe M., The People's Home. Social Rented Housing in Europe and America, Blackwell, Oxford 1995.

KWIATKOWSKI J., Partycypacja społeczna i rozwój społeczny, Agencja Wydawniczo-Reklamowa MT, Warsaw 2003.

MUCZYŃSKI A., Gospodarowanie gminnymi zasobami lokalowymi z perspektywy polityki mieszkaniowej, in: Studia i Materiały Towarzystwa Naukowego Nieruchomości, Vol. 19, No. 2, TNN, Olsztyn 2011.

REDMOND D., NORRIS M., Reforming Local Authority Housing Management: The Case of Tenant Participation in Estate Management, in: Housing Contemporary Ireland, Springer, Dublin 2007.

Somerville P., STEEle A., Making Sense of Tenant Participation, w: Housing and the Built Environment, Vol. 10, No. 3, 1995.

SUSZYŃSKA K., BARCZAK I., Ewolucja relacji klient - organizacja mieszkaniowa w świetle zmian paradygmatów zarzadzania, na przykładzie szwedzkich organizacji mieszkalnictwa społecznego, The Scientific Bulletin of the Department of Economic Journalism and Public Relations, Wyd. Uniwersytetu Ekonomicznego w Poznaniu, Poznań 2013.

SUSZYŃSKA K., Szwedzki rynek nieruchomości mieszkaniowych w świetle światowego kryzysu finansowego, in: Studia i Materiały TNN, vol. 20, No. 3, 2012.

TAYlOR M., Neighbourhood Governance: Holy Grail or Poisoned Chalice?, Vol. 18, No. 3, 2003.

WARD H., Tenant Participation From The Tenants' Point Of View, in: Davies, C. (ed.), Housing Management: Changing Practice, Macmillan Publishers, London 1992.

YIP N. M., Tenant Participation and the Management of Public Housing, The Estate Management Advisory Committee of Hong Kong, in: Property Management Vol. 19, No. 1, Hong Kong 2001.

SCB Report, Föreningslivet i Sverige: Välfärd, socialt kapital och demokratiskola. Rapport 98 i Levnadsförhållandeserien, 2005.

Boverket Report, Boendeinflytande i praktiken, Karlskrona 2010. 